LUKÁŠ STÁREK

ORCID 0000-0002-6068-215X

ELIŠKA BUCHTOVÁ

ORCID 0000-0001-5430-2846

Univerzita Jana Amose Komesnského Praha

Czech Republic

\title{
INCLUSION IN KINDERGARTEN, WITH AN ASPECT ON SOCIAL DISADVANTAGE
}

\begin{abstract}
Stárek Lukáš, Buchtová Eliška, Inclusion in Kindergarten, with An Aspect on Social Disadvantage [Inkluzja w przedszkolu: Kazus niekorzystnej sytuacji społecznej]. Studia Edukacyjne nr 59, 2020, Poznań 2020, pp. 311-334. Adam Mickiewicz University Press. ISSN 1233-6688. DOI: 10.14746/ se.2020.59.19
\end{abstract}

Social disadvantage is a construct that captures various dimensions of social position, such as economic status, educational attainment, as well as ethnicity. There is considerable evidence that social disadvantage is associated with emotional and behavioural problems in children (Bergin \& Bergin, 2015). Nowadays, the theme of inclusion is accurate hence the issue of social disadvantages is not topic just for the pedagogy and pedagogical workers. At the same level, the authors focus on social disadvantages children in kindergartens. A challenge for intervention includes that social disadvantage is often structural in nature and, as a result, is largely impervious to change. It has been found that much of the association of low family income with adverse child development is indirect, through more proximal processes such as parental mental health and the home environment, rather than direct. Therefore, it is crucial for pedagogical workers such as teacher, teacher assistants etc., to acknowledge the sensitivity of social disadvantages which a family can face to.

This chapter aims to highlights the issue of social disadvantages which can occur in kindergarten, with an emphasis on inclusion. By using the case studies the authors have found out how a status of a social disadvantage child influence a child and its family. Also, how this problematic is seen by pedagogical workers in chosen kindergarten.

Key words: case study, child, inclusion, kindergarten, preschool education, social disadvantage

\section{Definitions}

According to Felcmannová, Habrová et al. the social disadvantages are defined as:" .... a huge scale of reasons, not medical, which occur not in school but in natural social environment of a child, or in different life situa- 
tions which are not connected with school". ${ }^{1}$ Zíková et al. ${ }^{2}$ define the social disadvantages as " ... a moment, when a child has not enough possibility to fill its potential, due to long term problems with socio-economic situation in a family, or influence of risks factor on a child's development, or influence of elements of socio-economic differences, and the risk of combinations of the listed risks above". More common definition Průcha, Walterová and Mareš ${ }^{3}$ claim the social disadvantages are "... when one due to social hierarchy has restrict or harder conditions to get the social and material property". The term social disadvantages are also stated in the law, the Act no.561/2004 Coll. On Preschool, Primary, Secondary, Higher and University Education defines the social disadvantages as: "a) family environment with lower socio-culture state, with socio pathological risk, b) directed substitutional care or directed protective care, or c) a refugee wait to become a resident in the Czech Republic according to specific rules." More specific information defines Public notice no. 27/2016 Coll. About education of pupils with specific needs and gifted pupils, which states that social disadvantaged child is a child comes from family with low social status, where it does not get enough support in education. Often endangered by pathological issue, which come from substitutional care, protective care and refugees' families.

According to listed definitions, the authors state that all social disadvantaged children have one similar character. All children, and their abilities and possibilities are negatively influenced by their family and social status of the family where they are brought up. Secondly, the social environment where the children live and grow up has significant influence on them. Also, the cultural status of family and its own history have incredible influence on social status of children in kindergarten, already.

\section{The specific character of a social disadvantaged child in kindergarten}

The age when a child starts to visit a kindergarten or children's group is specific by its own dynamic. It is the age when a child starts to fully acknowledge the world around it, during this period the mental development is incredible. Therefore, the command for the best possible care in important. The kindergarten or children's group become another part of developmental process of a child. Hence, work with children at this age should be acknowledged, consistent and patient. AS said before, the influence of environment is significant as well.

\footnotetext{
1 L. Felcmannová, M. Habrová et al., Katalog podpůrných opatření: dílčí část pro žáky s potřebou podpory ve vzděláváni z důvodu sociálního znevýhodněni, Olomouc 2015, p. 9.

2 T. Zíková et al., Bedekr sociálním znevýhodněním pro učitele mateřské školy, Plzeň 2011, p. 12.

3 J. Průcha, E. Walterová, J. Mareš, Pedagogický slovník, Praha 2013, p. 6.
} 
The attention of social disadvantaged children is slower, and often there is visual or hearing problem, or lower intellect. Those children have problem with orientation in new situation. The children with hearing handicap, have significantly worst phonetic acknowledge and phonetic hearing, which lead to future ability of correct reading. The correct reading is crucial part of speech development and psychic development of a child. ${ }^{4}$

The children who are social disadvantaged is important to get the thinking process right, specially the correct order of the thinking process. It is important to get from concrete operations, throughout the half-abstract, to full abstraction. In thinking characters authors include, puerility, emotion, recognition processes tend to be stereotype and rigidity. The theoretical presentation (i.e. mathematic) must be easy, short and have practical examples such as visual aid. The social disadvantaged children often have problems with concrete think and often depends on their speech development, but it depends on concrete situation. The children often have not development free will, they are emotional immature and too emotional. The over emotional acting is influenced by over reactivity, which is caused by not ability to control their emotions. It is typical for social disadvantaged children to have problems with attentions, short term attention. Their behaviour is instant without any visible evidence of deeper reasoning. Very common attribute is that a social disadvantages child is not living in primary family but many of other relatives. Also, the families often do not share the culture values or principles, the parents can have problems with language, which lead to problems with words capacity, problems with use of grammatical rules and lower language system understanding. ${ }^{5}$

"The speech development and communication depend mainly on family environment, whereas it depends on individual abilities such as intelligence, temperament, predispositions from parents. In family environment, where parents do not give to a child enough impulses to use speech the development of speech is slower. Usually, it can happen in families where parents do not have questions for a child, or where instead of reading a book together with a child parents use other impulses such as television or nowadays computer". ${ }^{6}$ According to Zíková7 "The communication in social disadvantaged families is more focused on concrete person, things or situations". Often is linked to family connection, very concrete and without use of abstraction. During use

\footnotetext{
${ }^{4}$ M. Bartoňová, I. Bytešníková, M. Vítková, Děti se speciálními vzdělávacími potřebami v mateřské škole: texty k distančnímu vzdělávání, Brno 2012.

${ }^{5}$ Ibidem.

${ }^{6}$ J. Průcha, S. Kot'átková, Předškolní pedagogika: učebnice pro střední a vy̌̌ší odborné školy, Praha 2013, p. 42.

${ }^{7}$ T. Zíková et al., Bedekr sociálním znevýhodněním.
} 
of this type of communication the key role plays facial expressions, gestures, direct sentences, commands, and restrictions.

In case of social-cultural differences the biggest issue is in a language barrier. "The issue is often in families, where parents do not speak by Czech language. The children in these families often use the mother language at home, whereas they are forced to use the second language in school. Therefore, this could cause problems in education process. The children do not understand to instruction at school, they can have problems to express their thoughts and overall, they can have problems with social interaction". ${ }^{8}$ Vágnerová (2005) claims that for foreign children the interaction is society can be easier than for their parents. However, they could still have problems with vocabulary and correct using of grammatical rules. In the Czech Republic, the most disadvantaged group of children are Gypsy and Roma ethnic children. In social difference are included groups with different religion. ${ }^{9}$

\section{The used methodology}

The main aim of the research in this chapter, is to highlight the issue of social disadvantaged children and their status in the kindergarten. Another aim is to chart the pedagogical work done with chosen children. The part research's questions are conducted in three main areas:

1. How often does the child visit the kindergarten and what frequency does the visits have in chosen group of children?

2. Are the support provisions used for social disadvantaged children in the kindergarten?

3. How does the cooperation between the kindergarten and the parents of social disadvantaged children work?

4. What is the view of parents or kindergarten on diagnosis of the child?

According to the aims of the research and asked questions the authors decided to use qualitative approach in the case studies. Mainly, because this approach allows detail research of chosen topic in its real context. Also, the qualitative approach describes the issue in its complexity. The case studies of each child from social disadvantaged environment let the authors to understand to specific life situation of social life not just children, but their families and pedagogical workers in the kindergarten.

The qualitative research was conducted in the kindergarten which is placed in small village with 700 habitats in Vysočina district. The kindergarten relates to a primary school. The capacity of the kindergarten is

\footnotetext{
${ }^{8}$ Z. Němec et al., Asistence ve vzdělávání žáků se sociálním znevýhodněním, Praha 2014, p. 31.

${ }^{9}$ T. Zíková et al., Bedekr sociálním znevýhodněním.
} 
50 children and it is spilt in two classes. The firs class of the kindergarten is for younger children in the age of $2-4$, there is 18 children. In the second class of the kindergarten is 15 children in the age of 5-7. The kindergarten visits 33 children, so the capacity is not filled. The kindergarten has been opened in 1969 , since then many reconstructions were done. It is fully equipped, and it has own garden.

The kindergarten's curriculum is fully focused on children's interaction with the world around them and their lived reality. The children's need and interests are highlighted. The core method is a play and the aim of the educational process is the maximum possible social, physical, and psychical development. The content and volume of educational process is accurate to children's age, needs and possibilities. The kindergarten is supportive and completing the family upbringing throughout the professional process.

\section{The characteristic of research method and the description of researched groups}

The authors used in qualitative research many techniques such as case studies, observation, analysis of shared documentation, and semi-structured interview with pedagogical workers in the kindergarten.

Case studies. The case studies are usual method of a qualitative research which collects data from few subjects. The data are collected and compared together. The typical sign for case studies is very detailed and concrete description. The subject is observed and interviewed frequently, so the results are linked to wider picture. At the end is possible to do comparison or check the validity of results. ${ }^{10}$ For purposes of this paper the observed areas were personal anamnesis, family and health anamnesis, schools' and social anamnesis, and at the end the relationship between the kindergarten and family.

The Observation. The observation technique was chosen with the main aim to observe children with social disadvantages. Specially, to observe how they behave in group of children. Secondly, to observe how they react and cooperate with authorities and their family members, mainly siblings.

The analysis of shared documentations. The analysis of shared documentations has helped significantly to access detailed information, which are usually hard to access. Mainly, it helped to access old diagnosis and children's drawings. The principal of the kindergarten has supervised the process of reading the shared documents, and she helped to the authors to orient in the documentations as well.

The chosen children. The authors have conducted the research with three children from described kindergarten above. The children were from the sec-

${ }^{10}$ J. Hendl, Kvalitationí výzkum: základní metody a aplikace, Praha 2005. 
ond class of the kindergarten in the age 5-7. Th children were recommended by the principal of the kindergarten, who knows the social environment where the children come from.

Semi-structured interview. The semi-structured interview has been designed to meet the aims of the research. By using the method of semi-structured interview, the authors have had the draft which they have followed, but they have had the possibility to individualize the interview according to the needs of participants. Also, the ability to react participants' responses have played the key role in these interviews. Hence the interviews were done in the kindergarten the authors have had chance to compare the reality with respondents' answers. The respondents have had chance to choose where the interviews will be conducted. The interviews took place in the office of pedagogical workers in the kindergarten, which had the view located to the playroom. As respondents were chosen two teachers in the kindergarten and one teacher assistant, who works directly with the children. All respondents know the children, work with them and design work material for them. Also, they know children's family environment and they keep documentation about the children. The two teachers work in the kindergarten longer than 3 years and the teacher assistant works there longer than 1 year.

According to the sensitivity of the conducted research the ethic was considered more than one time. Therefore, the ethic provisions included not just sing of coyness, but it was about overall approach to the observe children and the respondents. The authors who have worked directly with children have been remaindered about the ethic, coyness and ethical work in the whole kindergarten. The core idea was rule by Jeřábek ${ }^{11}$ "Being moral means to behave on the moral level... The moral responsibility is combination of sensitivity, considerateness and basic thinking process. This moral receptibility can be separate in those categories:

- responsibility to the observed object;

- responsibility to the science, and profession;

- responsibility to your funder and submitter of your research."

The authors, therefore, keep anonymity of the kindergarten and the village where the kindergarten is place. Also, the anonymity of the children is kept, so the authors have changed the names of the chosen children. The names of the classes are anonymised, as well. Overall, the authors have been responsible to the subjects, respondents and to their selves, also. Hence, the findings can be shared with the professionals in the educational field.

\footnotetext{
${ }^{11}$ H. Jeřábek, Úvod do sociologického výzkumu, Praha 1992, p. 78.
} 


\section{The findings and discussion}

\section{Tereza}

Personal anamnesis. Tereza was born in January 2015. She lives and grows up in her family. Before she started visit the kindergarten, she was not involved in any of social groups organization. In the kindergarten she has adapted without problems. She does not need any co-players; she does not need friends to be able to play and have fun. However, the collective of the class do not involve her much, because of smell from cigarettes and some communicational problems.

Family anamnesis. Tereza comes from gypsy family which includes 7 members. The family lives in the same village as the kindergarten is. Tereza lives with her parents and 4 siblings. She is 5 years old and she is the second youngest member of her family. The significant influence on Tereza's bringing up has her oldest sister, who regularly takes her to the kindergarten. The communication is a bit hard with her parents because they do not bring her to the kindergarten, and they do not share the information. According to these reasons, more detailed information such as family relationship, or wishes we do not have.

Health anamnesis. Tereza's psycho-motorial development is significantly slower. She has problems with understanding to fluent speech and she cannot communicate with her peers. Therefore, the pedagogical workers in the kindergarten assume she has hearing problems. However, she has not visited a specialist, hence her parents are not able to do anything. Therefore, Tereza cannot hear the correct pronunciation and her pronunciation is different, so the communication is very difficult.

School anamnesis. Tereza does not fit in the class collective well, because of the smell from cigarettes and problems with communication. She is of the noisy children, who often do what they are not supposed to do. However, this is caused by the hearing problems and problems with understanding. Also, she is not working well in groups project and early mathematical skills. On the other hand, she is progressing in activities which involves easy motorial skills such as doing puzzles.

Tereza visit the kindergarten on regular schedule, without any problems. However, there are problems when she is not in the kindergarten. The parents are supposed to inform the kindergarten about her absence, but often the kindergarten know about the reason of her absence next day or even later. After few recommendations and questions about Tereza's absence the parents answered, "We are not paying it". The parents received on Tereza's up bringing some social funds, which covers her attendance and other funds linked with 
it. This example draws for us the picture about Tereza's parents and their relationship to law and money. Tereza go to the kindergarten usually around 7:30am, and she stays there till $4 \mathrm{pm}$.

Nowadays Tereza does not have any individual help, because her parents do not have any interest to visit a pedagogical-psychological office, where they would be able to get for Tereza an individual plan of education. However, the work with Tereza is very different from the work with her peers because she cannot concrete for long time and she does not understand to the instruction. While a groups project with other children and Tereza, the pedagogical workers are using several different ways to include her in the collective, and to support her skills and abilities.

One of the ways how to ensure that Tereza understand to the instruction is repetitive explanation of instruction. For example, the art activities, when the teacher gives exact instruction and Tereza needs to follow them. The best way is to place Tereza on the closest places to the teacher, so she can see what the teacher does and do it. Meanwhile children are working the teacher moderates their work. However, this make significant pressure on the teacher, who needs to be able to help other children. Both asked pedagogical workers have agreed that the teacher assistant would be a significant help.

Another problem which Tereza experience are her reactions to changes which can occur immediately. For example, the kindergarten restriction according to current situation with COVID-19. In normal situation children are raised to be independent so they bring their food by their selves or they make a table for them. Nowadays, they are waiting to be served by the teacher, thus Tereza's problems with changes she has problems with respecting the new rules and she is not following them.

While working with Tereza the pedagogical workers in the kindergarten are using her well-developed sensitive motorial skills. Thus, they found that is good to give her some of those tasks such as work with scissors, drawing or sticking the papers together.

Tereza's communication problems have significant influence on any diagnosis which should $b$ done. She is 5 years old, whereas her diagnosis corresponds with diagnosis of 3 years old child. However, in other ways of diagnosis she is on the right track i.e. visual perception is well-developed and she is able to follow any instruction which she receive by visual way. However, her abilities and skills are mirroring her understanding, thus it has an important impact on her development.

One of Tereza's teacher assumes, she could have a mental diagnosis. However, it is hard to support or negotiate that idea when a professional has not seen her. On the other, no one can say anything because in other areas of development she is very handy and clever. 
Overall, Tereza's is behind in many areas of development such as auditory area, speech, fundamental mathematical visualizations, and social skills. Thus, everything is influenced by her problems with understanding. For example, wile doing a task focused on orientation or tough motorial skills Tereza has problems to understand to the instructions. Therefore, the teacher often takes her hand and go throughout the details of each phase of the task. However, this slow the teacher and make it almost impossible for them to help the other children. Thus, the pedagogical workers mentioned again the need for a teacher assistant.

According to this, the principal of the kindergarten has decided to receive help from Temple for School III., which will start and she would like to ask for funding to be able to hire another teacher assistant, who would help in the whole kindergarten and especially to Tereza.

Social anamnesis. Tereza's integration in class' collective is complicated, thus her communication problems. Therefore, when classes are together i.e. at the kindergarten's garden she is usually with younger children around age of 2, who are at the same level of communication as she is. However, she is older than them and she likes to lead them and take care of them. However, sometimes Tereza has problems with understanding and them she tends to be aggressive. Because of her communication problems the teachers cannot find who did what and it is hard to find solution. Therefore, she often plays alone, and her favourite activities are drawing of doing puzzles.

Cooperation between the kindergarten and parents. As said before Tereza is often brought to the kindergarten by her older sister. Therefore, the cooperation with parents is quite complicated between the kindergarten and Tereza's parents. Sometimes the teachers try to contact them by messages send throughout Tereza's sister. However, often they do not receive any answers from parents. The teachers have tried to use email communication, but they have not received any answers neither.

Each second Monday the kindergarten organizes the afternoon with parents. The parents can come to the kindergarten and play with their children or craft something what the teachers have prepared for them. However, Tereza's parents have never come, and they have not used the opportunity.

The kindergarten is involved in supported program from The Government of Education and Physical Training called Templates for Schools II., which offers to schools finance for thematical meeting and cooperation with parents in the kindergarten, project days in the kindergarten or in other institutions. Tereza's parents have not been involved in opportunities to meet experts such as professionals from pedagogical-psychological office, or logopaedic specialist, or paediatric professionals. Her parents do not have any interest in any extra activities organized by the kindergarten. It has happened 
more than once, that her parents have not let Tereza to join any project days, because they fear funding and they do not know that it is paid from the templates. The kindergarten has informed Tereza's parents more than once that the extra activities are paid, thus they are not charged for it. The kindergarten has informed than by email or sharing the information on the kindergarten's notice board. However, reaction of the parents is still same, at the day of the activities Tereza do not come.

Retro perspective and perspective view. When Tereza started to visit the kindergarten she was not able to take care of her-self, she had problems with adaptation to new rules and to the new day system, she was not able to understand the authority of a teacher. She was not crying and had have problem with the change of environment.

The important and needed improvement has Tereza done because of teachers' work and the influence of other children. Even of Tereza's problem with communication and understanding, she has understood to the system of the kindergarten. Mainly, because the teachers have added repetitive rituals and systems, which she was able to learn and understand to them. The opinion of one of the teachers is that due to influence of other children, who were able to understand immediately Tereza was able to pick up on the rules and routines faster than without the impact of other children.

Tereza has undoubtedly improved in areas such as sensitive motorial skills, self-care and graphomotor skills. Mainly, the improvement is done because Tereza likes activities which involve these skills. Probably, she does not have many opportunities at home to draw, make puzzles etc. To the self-care children are led by the teachers every day.

In the future is significantly important to visit the specialist for diagnosis, thus when she understands to the instructions, she does not have any problems to finish a task.

\section{Milan}

Personal anamnesis. Milan was born in February 2013. Since he was born, he lives in his family with own mother and stepfather. In the class collective he is often dominant and aggressive, therefore he is not involved much because other children are not taking him in the collective. Milan cannot control his emotions.

Family anamnesis. Milan comes form family, which has 5 members. The family complete but with dysfunctional relationships. He lives with his stepfather, current boyfriends of his mother, his mother and two siblings, older sister who is 10 years old and youngers sister who is daughter of his stepfather and she is 3 years old. Family environment is unstable. His mother's boyfriend cannot control his emotions and he is very aggressive and uncon- 
trollable. Often Milan trash his older sister, climbs to the window and threats that he will jump out of it. Therefore, his mother has asked at the village office if they can provide her bars on the windows, thus she would be able to protect him. Milan's father is unknow, the teachers in the kindergarten have not seen him, and even Milan is not talking about him.

Health anamnesis. Milan have ADHD and concentration disorder. He comes from social disadvantaged family and the family's environment does not help him to develop normally. His parents receive social funds.

School anamnesis. Milan is one of the noisy children in the kindergarten, he cannot focus for longer time. He is aggressive and unkind to his classmates. Milan has an individual educational plan made by special pedagogist from pedagogical-psychological office. In the diagnosis he needs to work on areas linked with graphological skills, hearing and visual differencing throughout the logopaedic exercises, and emotional and social feelings. Milan has allocated a teacher assistant, who work with individually 30 minutes every day. Milan needs everlasting supervisor if the teacher leaves his he uses the situation. Milan is in pre-school class and he has one-year postponement to primary school.

Social anamnesis. Milan's relationship to his peers is complicated. While activities he claims the attention by vulgarisms and jokes. Whether he does not like the given tasks he reacts negatively and start to be aggressive and angry. The relationship between him and his family is same as in the kindergarten. He does not respect the teacher authority at all. Milan is aggressive especially to his older sister; he fears his stepfather. It has even happened that in the anger incidents his has peed. However, it happened that he peed on purpose because he did not like something.

Milan has problems with the kindergarten's attendance. The law says that the last of the kindergarten is compulsory, thus the parents need to fill the record of absence. Milan's absences are not often due to illness, and if they are, they are apologized. However, there are days when Milan does not come to the kindergarten, the reasons are cold, cough and running nose or family reasons. The real reasons of absence the teachers do not know, but sometimes Milan slips from mouth that mother did not wake up, or she did not want to. It is not usual, but Milan has most records of absence from his class. This issue can make it difficult for Milan's transfer to the primary school, where bigger number of absences can make it complicated for the whole educational process. The principal of the kindergarten has spoken with Milan's mother and make her aware of his attendance issues. However, the reaction was not adequate and Milan's mother answered that Milan has everything apologized. The kindergarten wants to transfer this information to Milan's future primary schools, to make sure they are aware of his attendance issues. Mainly, because 
Milan is not concentrated well and due to his diagnosis, the attendance issues can make the educational process difficult. Milan visits the kindergarten from 7am and leaves it after lunch. Originally, he slept in the kindergarten, but once he had a huge incident of anger and he hit the teachers. In the afternoon is in the kindergarten only one teacher, thus the kindergarten has agreed with Milan's mother that he will not stay in there.

By the pedagogical-psychological office Milan has been diagnosed on the second level of supportive provision. Therefore, the pedagogical workers work with Milan according to the individual educational plan done by special pedagogist. Often work with Milan the teacher assistant and teacher. In the chosen kindergarten a teacher does the diagnosis at first, after they stick with individual educational plan and they work together with a child on the areas where the improvement needs to be done. After the diagnosis is done, the teacher explains everything concretely to the teacher assistant, who then works with the child individually. The areas of needed development are chosen by the teacher, whereas the concrete exercises and activities can the teacher assistant find and supplement according to the individual educational plan of each child. Very crucial is for each cooperation between a teacher and a teacher assistant to communicate and share the information well. Milan has often emotional problems which are not usual at this age. One of the reasons which affects Milan's behaviour is unstable family environment, which often impact Milan's behaviour in the kindergarten. The teachers think that Milan knows well that his family is social disadvantaged, thus he is often showing off the things which he does not have, or he is talking about experiences and actions which he have not experienced and he is lying. The teachers are trying to explain him that lying is not right, but Milan reacts aggressively, and he uses vulgarisms. When a child has an anger episode the teachers try to calm him down by diverse ways such as separate the child from the group, they sit to him and touch his spinal trying to make the eye contact. Also, they talk with the child throughout the situation and why they have reacted certain way. In Milan's case this happens more than once in the week, but the way how to calm him down are not standardized. It has happened while the calming process that he has reacted aggressively, he has kicked the teacher. The teachers think that Milan is not use to physical contact such as hugs and caress. The pedagogical workers have agreed that Milan's mother should visit with him a specialist and psychologist help and if this would not help, they are considering letting know the social-work office. Thus, they are worried that Milan is bullied by his stepfather. Milan prescription for the medication on his behaviour disorder. He takes pills lowering his hyperactivity. The kindergarten cannot give any medicaments, but Milan's mother asked for it. However, the kindergarten has signed an agreement with Milan's mother that she agrees 
with giving the medicaments to her son by the teacher, and she is taking full responsibility for any complication which may arise.

The biological father is unknown thus, he does not visit the kindergarten. Also, the current partner of Milan's mother is able to pick up him from the kindergarten, but he has picked up him from there just twice. It was visible that Milan was not sure if he can go with him. Therefore, the cooperation is mainly done between Milan's mother and the kindergarten who usually pick up him. Also, she is the one who figures out any behaviour problems, it has happened more than once that she was asking for help with his behaviour. Also, the pedagogical-psychological office has given the recommendation to Milan's mother that he should be placed in the Children Psychiatric Hospital in Opořany, but his mother was against the recommendation. However, Milan's mother is available to help, kind and she is taking part in the kindergarten's activities.

Milan is very smart, but he is unkind and lazy to do tasks which he should do. When the task is interesting for him he has not problems to do it and he enjoys it, and the results are according to his age and sometimes over it. However, it happens that he does not find it interesting, thus he does it but not precisely or he does not do it at all. In the attachments the reader can find examples of tasks, the first Milan has enjoyed and the second he has not enjoyed. Milan is very hand boy and especially in areas involve logical thinking such as mathematical skills and logical thinking, the tasks linked with these areas he enjoys most. Therefore, the teachers are trying to use his interested in these areas. However more frequent are any behavioural issues which the teachers need to discus with Milan, thus it is important to appreciate Milan's work, when it is done correctly. It is crucial while figuring out any issues with Milan to let him calm down and then go throughout the conflict outside the class collective. It is important to let Milan built the sense of trust between him and the teachers. A working solution for Milan is support of the teacher assistant who is closer to Milan than the teachers.

Milan has not diverse educational plan and neither the assessments are different. However, he needs to have fixed rules, and no one can break them. For Milan is necessary to repeat which rules and norms are right and which not. While the group projects, is important to empower his concentration and his engagement in the collective and during the activity. The evaluation is done every day, whereas the bigger evaluation done with teacher and teacher assistant is done once per month. Also, once the week is cooperation between the kindergarten and Milan's mother, when she is very interested in him progress and behaviour. For development in the kindergarten Milan use several materials such as Logopedarium - exercising of speech muscles which follow schema of logopaedic; for orientation in space - ICT Speaking is game; for so- 
cial relationships - fixing the relationships in the collective; for graphomotor skills - Šimon's papers, The School's book of graphomotor skills, file Kytice; for concentration - ICT pairs, Beruška, Logikit, Logiko Primo, and at the end he use working sheet made by RVP PV. Because of use of all these materials and tools the pedagogical workers of the kindergarten can work fully on Milan's development in all areas.

Retro perspective and perspective view. When Milan started to visit the kindergarten, he had huge behavioural problems and the teachers could not control him. However, after he visited specialist from the pedagogical-psychological office, who assigned him for the second level of supportive provision. Another significant step was the medication which he started to use to control his hyperactivity, Thus, the medication Milan is now able to focus on the activities which he does in the kindergarten.

The final impact has on Milan's development the teachers and the teacher assistant who work with Milan on daily basis. They are trying to find way to ensure that Milan developing every day and that he is following the individual plan from the pedagogical-psychological office. Milan has made a significant improvement, from the start of his attendance in the kindergarten. He started visit the kindergarten when he was 5 years old, which was another complication in his inclusion in the kindergarten's collective. The postponement of the begging of his primary school attendance, which helped Milan with the integration in the class collective, has shown to be a great decision. It has helped with keep up with the school reediness and stabilization of Milan's behaviour, also.

In the future Milan should keep cooperating with the teacher assistant, who can support him and supervises him. Both asked teachers would like to convince Milan's mother to visit the psychologist with Milan. Thus, the psychologist will be able to work with Milan on his emotional discourse. Also, the specialist will be able to help him to understand to his reaction in the stress situation.

\section{Marcela}

Personal anamnesis. Marcela was born in April 2014, she come from noncomplete family, she lives with her mother and her grandmother. She is the only child in hr family. The family lives in the same village where the kindergarten is.

Family anamnesis. Marcela is the only child in her family, she lives with her mother and grandmother. From Marcela's behaviour is obvious that she is raised up by two women, and that she is missing the man in her life. The teachers in the kindergarten hear from Marcela's mother is can do it by her shelf, and that she does not need a man in her life. Marcela is spoiled by her 
mother and she has everything what she wants. On the other hand, she is rough to her and sometimes even unkind. Marcela's mother receive on her bringing up the social funds. The environment where Marcela comes from has a significant influence on her behaviour and her education. Marcela's mother visited the special school; therefore, it is possible that she inherited lower intellect.

Health anamnesis. Marcela's development is disharmonic. She has a hug problem with nose's and neck's tonsils, which do not allow her to pronounce correctly and in the future it could negatively influence her reading and writing skills. Marcela is intolerance for lactose; thus she needs to have special diet.

School anamnesis. Marcela has problems with understanding to instructions, and often she gives up a task because she does not feel the motivation. In the kindergarten she is the one who needs permanent attention. If the teacher does not give her the attention she starts to lie and anything to get the teachers' attention. She is very sensitive to children better than her and she is trying to keep up with them. However, it is difficult for her.

Marcela's knowledge is usual for her age, but it difficult for her to keep attention, or she does not understand to instructions or she does anything else. She has visited pedagogical-psychological office which has recommended postponement. She has also taken intelligence test. However, the results have been seen by the teachers. They assume that she has lower intelligence quotient.

Social anamnesis. In class collective Marcela is not a popular child. Thus, the children think she is not too smart. Also, they are bother by her lies and they recognize when she is lying because she is often flourish. She does not have many friends, but if she has some friends it is mainly because of new toy, which Marcela sometimes bring with her to the kindergarten. It happens that Marcela brings a new toy to the kindergarten, which she was previously talking about. Marcela is trying to be the teacher's favour, she repeats sentence and begs for attention.

Marcela attends the kindergarten regularly, usually from 7am till the lunch time, she is not sleeping in the kindergarten after the lunch. Whether Marcela is missing her mother apologize her immediately. However, her mother is overprotective if Marcela has running nose is not coming to the kindergarten. On the other hand, Marcela's mother needs to be informed about activities happing in the kindergarten. For example, from March till April the children were going to swimming lectures. Every child was going there, but Marcela's mother was worried that Marcela would get cold thus, she has not applied her for the swimming lectures. The teachers tried to explain Marcela's mother that after the lecture will be enough time for children to get them dry and that 
they will have enough time to eat the snack. However, Marcela's have not agreed. Marcela than was crying in the kindergarten because could not come with other. Her mother has told her that she will not go with other because she is often ill. Next days Marcela has come to the kindergarten and she has explained to everyone how bad is go for swimming in the winter, and that she will go to the swimming pool with her mother in the summer and even more often than other with the kindergarten. It is obvious that her mother has told her this to make her feel better. Therefore, the children in the kindergarten do not like Marcela because she has often something better than them and she is using to be flourish.

Marcela does not have supportive provision. She comes from social disadvantaged family and significant influence on her bringing up has her mother and grandmother. Marcela has by the pedagogical-psychological office recommended postponement and her mother has agreed with the recommendation. Therefore, she will be attending the kindergarten next year. During the morning circle, where children are sharing their story on a theme which is chosen by a teacher, Marcela has tendences to be the first child who will talk. Whether someone is the first she tends to stop them and the words or put her story in theirs. While working with her the teachers must give her a task when she will feel she is the important and needed. According to a teacher is hard to find the line when Marcela is able to work but the others are not jealous on her. In the class they are repeating some rituals, due to the teacher makes the children changing the task fairly. For example, the choice of a fairy tale before the children go to sleep. The teacher chooses one child's temple (a picture), the chosen child chooses the fairy tale and next the one who has chosen the fairy tale choose the one who will choose the fairy tale. By doing this the children are alternating without any problems. Another method which the teacher in Marcela's class use is the children yoga. Because the yoga is simply, and positions of animals are creative for children and they can make stories around it. The use of children's yoga can be used for development of fantasy and imagination. It is important to let children enjoy the moment when they can play without any rules. The teacher is Marcela's use dynamic and rhythmic exercises such as dance, while she let them jumps, scream and they feel her trust. This can help to children who are energic, whereas each of this exercise is finished with relaxation, group massage or breathing exercise. During the final relaxation children calm down. It is easier to do it with the final relaxation because children know that they very noisy and now it is time to calm down and start listen.

The cooperation with Marcela's mother is not easy for the kindergarten's teachers. It often happens that Marcela's mother makes it harder for teachers to be fair and she make it harder for them educate children fairly. For exam- 
ple, the kindergarten's mascot the fox Eliška. Each child can take the fox for a weekend to home. Marcela was angry at the begging because she cannot take the fox to home, so her mother bought her the same fox. This is very unmoral for Marcela because she got what she wanted but the other children needed to wait. Marcela's mother has often feelings that her daughter is the best and that she deserves everything. However, Marcela needs fixed rules. The kindergarten often communicates with Marcela's grandmother, who is strict to her, whereas she does not want to figure anything with the teachers in the kindergarten. The position of social disadvantaged child is very worrying for Marcela's mother who is trying to do everything to look like they are not socially disadvantaged.

Marcela is very purposeful child, she wants to be the best, thus she is trying to do everything to be the teachers' favour. Often it happens that she is ahead in things which they do in the kindergarten the teachers know she have learnt it at home. However, it takes away from her the surprise moment and new interest. Even though, she is trying at home and she knows a lot of things, she is not clever and during spontaneous activities she often says some nonsense. Marcela is not a stupid child she is average child something is easy for her and something is harder. However, the activities where she needs to use logic are harder for her. Marcela has problems in logopaedic areas such as hiss syllables (such as s) and phone R and $\check{R}$. According to these problems she is visiting an external specialist who works with her each week. She is very good in sensitive motorial skills.

Retro perspective and perspective view. When Marcela started visit the kindergarten she looked like a normal child. During her adaptation she had small problems with changes, but later she liked the kindergarten. From the begging there were no problems with Marcela and her parents, so the teachers worked with her like with others. Marcela was not too competitive, but later and with the influence of both women she started to want to be the best. Nowadays, Marcela is starting the kindergarten with one-year postponement. The postponement year will help Marcela to focus on tasks, improve her speech, coordinate work with other children and she will learn to tolerate the others thus improve her social behaviour.

\section{Comparison of collected data from the case studies}

In a table n.o.1 are summarized data from fundamental areas of each case study. The table simplify and categorize collected data. Therefore, a reader can see the target group, which are included in the research. 
Comparison of collected data from the case studies

\begin{tabular}{|c|c|c|c|}
\hline & Tereza & Milan & Marcela \\
\hline Age & 5 & 7 & 6 \\
\hline Family & $\begin{array}{l}\text { seven members, } \\
\text { gypsy technicity }\end{array}$ & $\begin{array}{l}\text { five members, step- } \\
\text { father }\end{array}$ & $\begin{array}{l}\text { only child, lives } \\
\text { with mother and } \\
\text { grandmother }\end{array}$ \\
\hline Health anamnesis & $\begin{array}{l}\text { no diagnosis, } \\
\text { assumptions about } \\
\text { hearing disorder }\end{array}$ & $\begin{array}{l}\text { ADHD, behaviour, } \\
\text { and attention di- } \\
\text { sorder }\end{array}$ & $\begin{array}{l}\text { intolerance for lac- } \\
\text { tose, problems with } \\
\text { nose's and neck's } \\
\text { tonsils }\end{array}$ \\
\hline Social disadvantage & $\begin{array}{l}\text { yes, different cultu- } \\
\text { ral environment }\end{array}$ & $\begin{array}{l}\text { yes, dysfunctional } \\
\text { family relationships }\end{array}$ & $\begin{array}{l}\text { yes, she lives only } \\
\text { with mother }\end{array}$ \\
\hline $\begin{array}{l}\text { Receiving the social } \\
\text { funds }\end{array}$ & yes & yes & yes \\
\hline $\begin{array}{l}\text { The pedagogical } \\
\text { workers }\end{array}$ & $\begin{array}{l}\text { the principal of the } \\
\text { kindergarten, the } \\
\text { class teacher }\end{array}$ & $\begin{array}{l}\text { the principal of the } \\
\text { kindergarten, the } \\
\text { class teacher, the } \\
\text { teacher assistant }\end{array}$ & $\begin{array}{l}\text { the principal of the } \\
\text { kindergarten, the } \\
\text { class teacher }\end{array}$ \\
\hline Attendance & $\begin{array}{l}\text { without problems, } \\
\text { sleeps in the kinder- } \\
\text { garten }\end{array}$ & $\begin{array}{l}\text { significant differen- } \\
\text { ces, not sleeping in } \\
\text { the kindergarten }\end{array}$ & $\begin{array}{l}\text { without problems, } \\
\text { not sleeping in the } \\
\text { kindergarten }\end{array}$ \\
\hline $\begin{array}{l}\text { Apologizes for mis- } \\
\text { sing }\end{array}$ & $\begin{array}{l}\text { no information } \\
\text { from parents }\end{array}$ & without problems & without problems \\
\hline $\begin{array}{l}\text { After school acti- } \\
\text { vities }\end{array}$ & $\begin{array}{l}\text { without parents' } \\
\text { interest }\end{array}$ & $\begin{array}{l}\text { partly they take part } \\
\text { in the activities }\end{array}$ & $\begin{array}{l}\text { attendance only } \\
\text { with mother's per- } \\
\text { mitions and only in } \\
\text { special occasions }\end{array}$ \\
\hline $\begin{array}{l}\text { Level of supportive } \\
\text { plan }\end{array}$ & without any plan & $\begin{array}{l}\text { the second level, } \\
\text { made by pedago- } \\
\text { gical-psychological } \\
\text { office }\end{array}$ & $\begin{array}{l}\text { the first level, follo- } \\
\text { wed by the kidener- } \\
\text { garten }\end{array}$ \\
\hline Individual plan & $\begin{array}{l}\text { without plan, but it } \\
\text { would be helpful }\end{array}$ & yes & no \\
\hline Teacher assistant & $\begin{array}{l}\text { without but it wo- } \\
\text { uld be significant } \\
\text { help }\end{array}$ & yes & no \\
\hline $\begin{array}{l}\text { Postponement of } \\
\text { primary school } \\
\text { attendance }\end{array}$ & not yet & yes & yes \\
\hline
\end{tabular}




\begin{tabular}{|c|c|c|c|}
\hline $\begin{array}{l}\text { Sensitive motorial } \\
\text { skills }\end{array}$ & usual for her age & $\begin{array}{l}\text { low, not coopera- } \\
\text { ting }\end{array}$ & usual for her age \\
\hline $\begin{array}{l}\text { Rough motorial } \\
\text { skills }\end{array}$ & low & usual for his age & usual for her age \\
\hline $\begin{array}{l}\text { Visual perception } \\
\text { and memory }\end{array}$ & usual for her age & usual for his age & with problems \\
\hline $\begin{array}{l}\text { Hearing skills and } \\
\text { memory }\end{array}$ & very low & usual for his age & usual for her age \\
\hline $\begin{array}{l}\text { Graph motorial } \\
\text { skills }\end{array}$ & usual for her age & low & with problems \\
\hline Drawing kills & usual for her age & low & low \\
\hline Speech & very low & $\begin{array}{l}\text { usual for his age } \\
\text { with little problems }\end{array}$ & with problems \\
\hline Space perception & with problems & usual for his age & with problems \\
\hline Time perception & with problems & usual for his age & usual for her age \\
\hline $\begin{array}{l}\text { Basic mathematical } \\
\text { skills }\end{array}$ & significant problems & usual for his age & with problems \\
\hline Social skills & significant problems & with problems & with problems \\
\hline Play & $\begin{array}{l}\text { depends on type } \\
\text { of game, problems } \\
\text { make didactic and } \\
\text { social games }\end{array}$ & $\begin{array}{l}\text { usual for his age, } \\
\text { constructive games } \\
\text { are better }\end{array}$ & $\begin{array}{l}\text { usual for her age, } \\
\text { problematic are } \\
\text { social games }\end{array}$ \\
\hline $\begin{array}{l}\text { Selfcare and inde- } \\
\text { pendency }\end{array}$ & $\begin{array}{l}\text { usual for her age } \\
\text { (problems with } \\
\text { dressing up) }\end{array}$ & usual for his age & usual for her age \\
\hline $\begin{array}{l}\text { Teachers' access to } \\
\text { the child }\end{array}$ & $\begin{array}{l}\text { individual care and } \\
\text { rituals }\end{array}$ & strict rules & individual care \\
\hline Method of work & $\begin{array}{l}\text { according to the- } \\
\text { matical educational } \\
\text { plan }\end{array}$ & $\begin{array}{l}\text { according to the- } \\
\text { matical educational } \\
\text { plan }\end{array}$ & $\begin{array}{l}\text { according to the- } \\
\text { matical educational } \\
\text { plan }\end{array}$ \\
\hline $\begin{array}{l}\text { Cooperation with } \\
\text { family }\end{array}$ & $\begin{array}{l}\text { complicated com- } \\
\text { munication thro- } \\
\text { ughout older sister }\end{array}$ & $\begin{array}{l}\text { usual, only with } \\
\text { problems when is } \\
\text { needed to over talk } \\
\text { behavioural pro- } \\
\text { blems }\end{array}$ & $\begin{array}{l}\text { complication, not } \\
\text { good mother's un- } \\
\text { derstanding }\end{array}$ \\
\hline $\begin{array}{l}\text { Visit of pedagogi- } \\
\text { cal-psychological } \\
\text { office }\end{array}$ & $\begin{array}{l}\text { no (without pa- } \\
\text { rents' interest) }\end{array}$ & yes & yes \\
\hline
\end{tabular}

Source: the authors of the paper. 


\section{Results and final discussion}

What is the attendance of a child in the kindergarten and how often does the child in the target group visit the kindergarten?

Thanks to documentation such as class book, attendance book and apologize papers, which the authors have change to see, the authors claims that the attendance is similar in the target groups. During interviews with teachers the questions has been answered. The main problems have been classified as problem with parents' responsibility and apologizes for missing. It is said in the law, that apologizes are compulsory only if the child is in the year of preschool education. Therefore, the main problem with attendance is falling on parents and not on children. In the conducted research (GAC, 2009) which was focused on attendance of social disadvantaged children in the primary school. The results have shown that the children's missing is often caused by many diverse reasons such as parents' irresponsibility, the parents' unemployment, other responsibilities linked with life in different community. In conducted case studies Tereza's parents do not feel any responsibility to apologize for her, Milan's attendance is unfrequented, it depends on family's situation. Marcela's attendance is frequent; her mother apologizes her immediately. According to the teachers it depends on parents' responsibility again. However, the teachers claim that frequent attendance is crucial for successful begging of school attendance.

Are for social disadvantaged children used supportive provisions in the kindergarten?

In the chosen kindergarten is for one child used supportive provision on the second level which was recommended by the pedagogical-psychological office. For the second child is prepared by the kindergarten the supportive provision on the first level, which aims to provide individual support while giving the instructions. Due to supportive provisions there is a teacher assistant who help while children are educated. Each child with supportive provisions has individual educational plan, which is key for successful educating process. Therefore, each teacher can than work with each child individual according to their needs and abilities. During the interviews was obvious that teachers know what hey are doing while preparing the individual plans and working with children.

How does the cooperation between the kindergarten and the parents of social disadvantaged children work?

Whether the authors look at the social disadvantaged children in the chosen kindergarten throughout the three chosen children, the authors find out 
that the parents' cooperation, communication and engagement is crucial. The parents influence by their opinions and relationships with teachers the children's behaviour. However, the three case studies have shown that the communication with parents is complicated in social disadvantaged families. In Tereza's case the parents were not interested in her education and they have not communicated and cooperate with the kindergarten. Milan's parents were interested and able to cooperate with the kindergarten but only if it was about positive things. In the last case, Marcela's mother have not cooperated with the kindergarten at all, sometimes Marcela's mother has conflicts with the teachers. Even thought, the kindergarten organizes many activities, even just for parents, the social disadvantaged families in this research are not taking part.

\section{What is the view of parents or kindergarten on diagnosis of the child?}

In Tereza's case the diagnosis is very hard, thus she cannot understand to the instruction. Also, it is obvious that she is not develop and supported at home. Milan has one-year postponement. Therefore, he is older in his class. His diagnosis is better than in previous years. He made significant progress when the pedagogical workers started to use the individual educational plan, which is made by the pedagogical-psychological office. Marcela is in the last pre-school year, but she has problems in many developmental areas, so the one-year postponement was recommended to her. It is obvious that a significant influence have on a child behaviour and schools' results the parents' attitude for example Marcela is trying at home, so she is ahead in the kindergarten. On the other hand, Tereza does not have at home many impulses.

According to the teachers it is crucial to work differently with the social disadvantaged children. It is important to keep the individual attitude to each child, use diverse method of work with children and keep the motivation high. Whether the authors conclude these three cases it is not just about integration of children but also about parents' integration. If the parents' feel good in the kindergarten and they respect teachers, they can develop the child. Even the special pedagogical attitudes are influence by the parents' agreement or disagreement with chosen method.

\section{Conclusion}

The problematic of social disadvantaged children and compulsory pre-primary school year are actual theme not just for teachers in kindergartens. The aims of compulsory pre-primary school year are equalizing the developmental differences in children development, eliminate handicaps which they 
bring from families and easier the beginning of primary schooling. The question is in which level these aims are completed. The children from the social disadvantaged families not always visit the kindergarten. The environment where they live is not always stimulating enough for the equal development. The kindergarten is place where they can get the potential, familiarize with many activities and rituals.

The important thought, support of children's the development should be crucial for each teacher and teacher assistant. The idea that the development of each child is important for future career and building the basic for future educational process, cannot be taken away from children due to non-activity of their parents or social disadvantages. The limits in family's cooperation and communication cannot stop the pedagogical work and its influence on children's development. Therefore, the pedagogical workers should offer friendly and partner's attitude and work, which could change life of many children.

The main challenge is link families of children who visit the kindergarten and continue developing the idea of active family and child from social disadvantaged environment. Due to this attitude the next generation can be influence by this positive thinking. Thus, it can help to build next positive and engaging generation.

\section{BIBLIOGRAPHY}

Act No. 561/2004 Coll., On pre-school, primary, secondary, tertiary professional and other education (Education Act). In: Collection of laws of the Czech Republic.

Bartoňová M., Bytešníková I., Vítková M., Děti se speciálnimi vzdělávacími potřebami v materšké škole: texty k distančnímu vzdělávání, Paido, Brno 2012.

Bergin Ch.C., Bergin D.A., Child and Adolescent Development in Your Classroom, Cengage Learning, Stamford 2015.

Blaštíková L., Významné oblasti pozitivniho klimatu školy v kontextu vybraných modelů, Lifelong Learning - celoživotní vzdělávání, 2018, 8, 1, p. 25-41. Dostupné z: https://lifelonglearning.mendelu.cz/wcd/w-rek-lifelong/111801/_1l1_1801_web_clanek2.pdf

Buchtová E.. Speciálně pedagogické přšstupy vybrané materšsé školy $k$ dětem ze sociálně znevýhodněné rodiny, Univerzita Jana Amose Komenského, Praha 2020 (Bakalářská práce).

Búgelová T., Lacková D., Vztăh ku škole a školskej práci z pohláadu žiakov zo sociálne zneoúhodněného prostredia z rómskéo etnika, Štúdie zo špeciálnej pedagogiky/SpecialEducation Studies, 2017, 6, 1. Dostupné z: https://www.unipo.sk/public/media/26527/Studies\%20in\%20Special\%20Education\%202017,\%20vol.\%206,\%20n.\%201.pdf

Daly A., Ruxton S., Schuurman M., Challenges to children's rights today: what do children think? Council of Europe, Strasbourg 2016.

Danielsbacka M. et al., Educational Test Scores among Adolescents in Three-Generational Households in 20 countries, Finnish Yearbook of Population Research, 2017, 51.

Davies M., Social Work with Children and Families, Palgrave Macmillan, New York 2012. 
Decree No. 27/2016 Coll., On the education of pupils with special educational needs and gifted pupils. In: Collection of Laws of the Czech Republic.

Felcmannová L., Habrová M. et al., Katalog podpưrných opatření: dílči část pro žáky s potřebou podpory ve vzdělávání z důvodu sociálního znevýhodnění, Univerzita Palackého v Olomouci, Olomouc 2015.

GAC, Vzdělanostni dráhy a vzdělanostni šance romských žákyň a žákư základních škol v okoli vyloučených romských lokalit, MŠMT, Praha 2009.

Haine-Schlagel R., Walsh N.E., A review of parent participation engament in child and family mental health treatment, Clinical Child and Family Psychology Review, 2015, 18.

Härkönen J., Bernardi F., Boertien D., Family Dynamics and Child Outcomes: An Overview of Research and Open Questions, European Journal of Population, 2017, 33(2).

Havlík R., Kot’a J., Sociologie výchovy a školy, Portál, Praha 2011.

Hendl J., Kvalitationí oýzkum: základní metody a aplikace, Portál, Praha 2005.

Hotz V., Pantano J., Strategic parenting, birth order, and school performance, Journal of Population Economics, 2015, 28(4), October.

Hrbáčková K., Šafránková P.A., Vnímání vlastní účinnosti pedagogických pracovníků v oblasti institucionální péče o děti a mládež, Sociální Pedagogika/Social Education, 2015, 3(2).

Jeřábek H., Úvod do sociologického výzkumu, Carolinum, Praha 1992.

Jeynes W.H., A meta-analysis: the relationship between father involvement and student academic achievement, Urban Education, 2015, 50.

Jurovičová D., Žáčková H., Dysgrafie, D\&H, Josefov 2009.

Kaleja M. et al., Edukace dětí předškolnîho věku se speciálními vzdělávacími potřebami, Ostravská univerzita v Ostravě, Pedagogická fakulta, Ostrava 2014.

Kaleja M., (Ne)prípravený pedagog a žák z prostředí sociální exkluze, Slezská univerzita v Opavě, Fakulta veřejných politik, Opava 2015.

Kaleja M., Determinanty edukace sociálně vyloučených žáků z pohledu speciální pedagogiky. Ostravská univerzita v Ostravě, Pedagogická fakulta, Ostrava 2014.

Kim S.W., Hill N.E., Including fathers in the picture: a meta-analysis of parental involvement and students' academic achievement, Journal of Educational Psychology, 2015, 107.

Lee E.V., Burkam D.T., Inequality at the starting gate. Social background differences in achievement as children begin school, Institute of Economic Policy Institute, Washington 2002.

Leirman W., Čtyři kultury ve vzdělávání - expert, inženýr, prorok, komunikátor, Karolinum, Praha 1996.

Liba J., Prozdravotná edukácia ako stratégia prevencie zdravotných a sociálnopatologických problémov u rómskych žiakov zo sociálne znevýhodněného prostredia, Štúdie zo špeciálnej pedagogiky/SpecialEducation Studies, 2019, 8, 2. Dostupné z: https://www.unipo.sk/public/media/26527/Studies \%20in \%20Special \%20Education $\% 202019, \% 20$ vol. $\% 208, \% 20$ n. \%202.pdf

Linhart J. et al., Velký sociologický slovník, Nakladatelství Karolinum, Praha 1996.

Matějů P., Večerník J., Zpráva o vývoji české společnosti 1989-1998, Academia, Praha 1998.

Matoušek O., Koláčková J., Kodymová P., Sociální práce v praxi, Portál, Praha 2010.

Mertin V., Gillernová I., Psychologie pro učitelky mateřské školy, Portál, Praha 2015.

Možný I., Sociologie rodiny, Sociologické nakladatelství, Praha 2002.

Němec J., Vojtová V., Inkluzivní vzdělávání jako faktor socializace dětí se sociálním znevýhodněnim, [in:] Vzdělávání žáků se sociálním znevýhodněním: Education of socially disadvantaged pupils, Eds. J. Němec, V. Vojtová, Paido, Brno 2009.

Němec Z. et al., Asistence ve vzdělávání žáků se sociálním znevýhodněním, Nová škola, Praha 2014. 
Osborn A.F., Resilient children: A longitudinal study of high achieving socially disadvantaged children, Early Child Development and Care, 1990, 62.

Pavan R., On the Production of Skills and the Birth-Order Effect, The Journal of Human Resources, 2016. Dostupné z: http:/ / eds.b.ebscohost.com/eds/pdfviewer/pdfviewer?v $\mathrm{id}=1 \&$ sid=66ba935b-c27b-4ae8-b8cce78eaad9fc5c\%40sessionmgr103

Předškolní klub Amálka př̀ručka dobré praxe. Spolupráce s rodiči dětí ze sociálně znevýhodněného prostředí. (2016). Dostupné z: http://www.amalthea.cz/data/File/metodiky\%20 ke\%20stazeni/PUBLIKACE_predskolni_klub_FINAL_nahled.pdf

Průcha J., Kot'átková S., Předškolní pedagogika: učebnice pro střední a vyšší odborné školy, Portál, Praha 2013.

Průcha J., Walterová E., Mareš J., Pedagogický slovník, Portál, Praha 2013.

Rabušicová M., Pol M., Vztahy školy a rodiny dnes: hledání cest k partnerství, Pedagogická fakulta Univerzita Karlova, Pedagogika 46, Praha 1996.

Seifert M. et al., Vzděláváni dětí se sociálním znevýhodněním v základní škole, Národní ústav pro vzdělávání, Praha 2019.

Šmelová E., Mateřská škola a její učitelé v podmínkách společenských změn: teorie a praxe II, Univerzita Palackého v Olomouci, Olomouc 2006.

Šojdrová M. et al., Rovný přístup ke vzdělávání v České republice: situace a doporučení, 2014. Dostupné z: https://www.csicr.cz/getattachment/cz/Dokumenty/Publikace/ Rovny-pristup-ke-vzdelavani-v-CR-situace-a-dop/Rovny_pristup_ke_vzdelavani.pdf

Stárek L., Definition of Substitute Family Care and Issues of the School Environment, Journal of Education and Training Studies, 2020, 8, 9.

Stárek L., Klugerová J., Education of First Grade Pupils in Protection Topics in the Czech Republic - Central Europ, World Journal of Education, 2020, 10.

Svobodová R., Role učitele, limity role, míchání rolí, 2012. Dostupné z: https:/ / clanky.rvp.cz/ clanek/c/p/17781/ROLE-UCITELE-LIMITY-ROLE-MICHANI-ROLI.html/

Vlach J., Úspěšnost dětí z dětských domovio v sekundárním a terciárním vzdělávání - Porovnání pohledu klientů a jejich vychovatelů, Sociální pedagogika/Social Education, 2017, 5(2).

Vuorinen T., Sandberg A., Sheridan S., Williams P., Preschool teachers' views on competence in the context of home and preschool collaboration, Early Child Development and Care, 2014, 184.

Zíková T. et al., Bedekr sociálním znevýhodněním pro učitele mateřské školy, Západočeská univerzita, Plzeň 2011. 